\title{
Ultrastructural observations on the phagocytic behavior of winter flounder Pleuronectes americanus peritoneal neutrophils and macrophages in vivo
}

\author{
Joel E. Bodammer ${ }^{1, *}$, Richard A. Robohm ${ }^{2}$ \\ ${ }^{1}$ URI/NOAA Cooperative Marine Education and Research Program, Department of Fisheries, Animal and Veterinary Science, \\ University of Rhode Island, Kingston, Rhode Island 02881, USA \\ ${ }^{2}$ National Oceanic and Atmospheric Administration, National Marine Fisheries Service, Northeast Fisheries Center, Milford, \\ Connecticut 06460 , USA
}

\begin{abstract}
A qualitative electron microscopical examination of peritoneal phagocytes in winter flounder Pleuronectes americanus after brief (i.e. 30 or $60 \mathrm{~min}$ ) exposure to formalin-killed Bacillus cereus or Yersinia ruckeri revealed that both neutrophils and macrophages had phagocytozed bacteria. Neutrophils obtained from both the peritoneal cavity and from the head kidney were identified on the basis of their overall cytological appearance and more specifically on the presence of elongated, striated (fibrillar) appearing granules in their cytoplasm which stained positively for peroxidase. Macrophages recovered from the peritoneal cavity were phagocytic like neutrophils; however, they were not observed to contain peroxidase. The surface membrane changes observed for 'activated neutrophils and macrophages which had engulfed bacteria were consistent with those reported for other fish species and higher vertebrates. Images of aggregated cells suggestive of cellular communication between lymphocytes, macrophages, and/or neutrophils are provided.
\end{abstract}

KEY WORDS: Winter flounder Ultrastructure Peritoneal phagocytes $\cdot$ In vivo

\section{INTRODUCTION}

As indicated in a number of recent reviews (Blazer 1991, Ainsworth 1992, Hine 1992, Secombes \& Fletcher 1992), the phagocytic behavior of both macrophages and neutrophils plays an important role in the nonspecific defense mechanisms of teleost fish. Although the cytological characteristics and phagocytic nature of both these cell types have been extensively studied in certain groups of fishes (e.g. salmonids, cyprinids, and ictalurids), much less is known about their morphology and function among the pleuronectiformes. Presently, the plaice Pleuronectes platessa is the only flatfish species, the peritoneal macrophages and neutrophils of which have been studied with respect to their ultrastructure and function (MacArthur et al. 1984, 1985, MacArthur \& Fletcher 1985). Regarding function, plaice macrophages and neutrophils were shown to engulf oyster glycogen and the marine bacterium Vibrio alginolyticus.

The winter flounder Pleuronectes americanus is an important commercial, recreational, and research species along the northeast coast of the United States. Reduction in stocks is being extensively investigated with respect to such factors as overfishing, habitat loss, and the effects of pollution (Murchelano 1989, Murchelano \& Wolke 1991). With the exception of the earlier work of Bridges et al. (1976) on the basic hematology of winter flounder and an in vitro study on the phagocytic and bactericidal capability of their macrophages (Daniels 1988), there are no detailed studies on the leukocytes of this species. Our knowledge of the immune system in winter flounder is at present limited to studies on their antibody responses after exposure to 
a variety of antigens under either natural (Robohm et al. 1979) or experimental conditions (Stolen et al. 1984, 1985, Laudan et al. 1987, 1989).

The purpose of this study was to define the in vivo ultrastructural and cytochemical (peroxidase staining) characteristics of peritoneal macrophages and neutrophils of this infrequently studied species after short periods (30 to $60 \mathrm{~min}$ ) of exposure to formalin-fixed Bacillus cereus or Yersinia ruckeri.

\section{MATERIALS AND METHODS}

Fish. The 14 winter flounder $(15$ to $25 \mathrm{~cm}$ in total length) used in this study were collected by trawling in the Atlantic Ocean along the coast near Cape May, New Jersey (USA). The fish were transported to the National Marine Fisheries Service Laboratory at Oxford, Maryland (USA) where they were maintained for at least 1 wk before experimentation. Fish were housed in four $100 \mathrm{l}$ aquaria receiving flowing seawater $(12 \%)$ at a temperature of 12 to $13^{\circ} \mathrm{C}$. The fish were fed chopped clams (Mya arenaria) ad libitum every other day.

Leukocyte preparations. Peritoneal cells were harvested from all fish by anaesthetizing them with MS-222, killing them with a blow to the head, swabbing the abdomen with $70 \%$ alcohol, and incising the lateral body wall. The exposed abdominal cavity was vigorously rinsed with $3.0 \mathrm{ml}$ of sterile tissue culture medium (STCM) and the harvested cells from 2 fish in each experiment were pooled. The pooled cells were pelleted by centrifugation at $1.000 \times g$ for 5 min before being fixed for electron microscopy as described below. In order to preserve the leukocytes as rapidly as possible, no attempt at washing or cell purification was made. Consequently, the cell preparations were moderately contaminated by red blood cells introduced from the edges of the abdominal incision.

Peritoneal leukocytes from control fish. Peritoneal leukocytes serving as controls were obtained from 2 fish after intraperitoneal (i.p.) injection with $0.5 \mathrm{ml}$ of STCM at 0 and 30 min with the leukocytes being recovered $60 \mathrm{~min}$ after the initial injection $(0 \mathrm{~min})$. The STCM used in this set of experiments and for peritoneal leukocytes exposed to formalin-killed Bacillus cereus (see below) consisted of: $91 \%$ Minimal Essential Medium, Eagle-Earle Base, $22 \mathrm{mM}$ sodium bicarbonate, $62 \mathrm{mM}$ L-glutamine, $9.0 \%$ fetal bovine serum (heat inactivated at $56^{\circ} \mathrm{C}$ for $30 \mathrm{~min}$ ), 20 USP units $\mathrm{ml}^{-1}$ heparin sodium salt, $62 \mathrm{mM}$ additional sodium chloride, 100 I.U. ml ${ }^{-1}$ penicillin G potassium, and 100 I.U. $\mathrm{ml}^{-1}$ streptomycin sulfate.

Peritoneal leukocytes from fish exposed to Bacillus cereus. Eight flounder ( 4 fish per group) were injected i.p. with formalin-fixed, washed Bacillus cereus $(1 \times$ $10^{8}$ cells $\mathrm{ml}^{-1}$ suspended in STCM. Group 1 consisted of 4 fish injected with $0.5 \mathrm{ml}$ of bacterial suspension; leukocytes were collected from the fish at $30 \mathrm{~min}$ postinjection. Group 2 consisted of 4 fish injected with $0.5 \mathrm{ml}$ of bacterial suspension at $0 \mathrm{~min}$ and again at 30 min; leukocytes were collected from these fish $60 \mathrm{~min}$ after the time of their first injection (0 min).

Cell preparation for conventional electron microscopy. All of the routine (non-peroxidase) preparations of leukocytes examined in this study were fixed by first pelleting the cells and then resuspending them in cold (0 to $4{ }^{\circ} \mathrm{C}$ ), $2 \%$ glutaraldehyde in $0.1 \mathrm{M}$ phosphate buffer (ph 7.4) for 24 to $48 \mathrm{~h}$. The cells were then washed $(4 \times)$ in cold $\left(0\right.$ to $\left.4^{\circ} \mathrm{C}\right)$ buffer and allowed to adjust to room temperature. Post-fixation of the leukocytes was accomplished in $1 \%$ osmium tetroxide in $0.1 \mathrm{M}$ phosphate buffer (ph 7.4) for $1 \mathrm{~h}$ at room temperature. Subsequentiy, the cells were stained en bloc in uranyl acetate following the method of Terzakis (1968) and dehydrated in a graded series of ethanols and propylene oxide. Infiltration and embedment of the cells was accomplished in resin (Spurr 1969). Thick sections ( 1 to $2 \mu \mathrm{m}$ ) were cut with glass knives and stained with toluidine blue dye. Selected areas were thin sectioned ( 60 to $90 \mathrm{~nm}$ ) with diamond knives and stained with uranyl acetate and lead citrate before examination and photography with a Zeiss EM9 S2 electron microscope.

Peroxidase evaluation. Peritoneal leukocytes for peroxidase studies were obtained from 4 fish after injecting them i.p. with $1 \mathrm{ml}\left(1 \times 10^{8}\right.$ cells $\left.\mathrm{ml}^{-1}\right)$ of formalinkilled, washed Yersinia ruckeri suspended in Earle's Minimal Essential Medium (EMEM) supplemented with $2 \%$ fetal bovine serum as per the recommendation of D. P. Anderson (pers. comm.). The leukocytes were collected from the peritoneal cavity after $60 \mathrm{~min}$ as described above. Cells were prepared for peroxidase staining at $\mathrm{pH} 7.6$ by the diaminobenzidine (DAB) method of Bielek (1981). Peritoneal leukocytes exposed to $Y$ ruckeri that served as controls for the cytochemical test were incubated without DAB. Although peritoneal leukocytes that had not been exposed to the bacteria were not available for peroxidase evaluation, head kidney tissue from the fish used in these experiments was removed immediately after collection and fixation of the peritoneal leukocytes. The kidney tissue was then minced into small pieces while still in fixative and subsequently processed for peroxidase evaluation (including controls incubated without $\mathrm{DAB}$ ) as described above. Upon completion of the cytochemical procedures, all peritoneal cells and head kidney tissue were post-fixed and embedded as described above for conventional electron microscopy. The cytochemically treated leukocytes were lightly 
stained after thin sectioning with alcoholic uranyl acetate to facilitate their identification.

\section{RESULTS}

Peritoneal neutrophils from control fish injected i.p. with STCM (Figs. $1 \& 2$ ) and some of those recovered from fish (Fig. 3) at 30 min post-injection with STCM and Bacillus cereus had a quiescent appearance (i.e. lacked well developed pseudo- or lamellipodia or internalized bacteria); in addition, they were round to oval in form and demonstrated only slight undulations of the plasma membrane. Their nuclei were horseshoeshaped and demonstrated a dense band of heterochromatin both peripherally and as islands within the nucleoplasm. The cells were approximately 7 to $8 \mu \mathrm{m}$ in length and 4 to $6 \mu \mathrm{m}$ in width, and their cytoplasm contained modest amounts of rough endoplasmic reticulum membranes, a readily recognized Golgi complex (GC; Fig. 3), dense, elongate mitochondria which varied considerably in form, numerous anastomosing tubules of smooth endoplasmic reticulum (SER; Fig. 4). and glycogen-like particles. Fine filaments (F; Figs. 4 \& 5) were observed in the cells' moderate surface elaborations and subjacent to its plasma membrane. The striated granules (SG; Figs. 1 to 3) typically found within their cytoplasm were revealed in some planes of section (Figs. $4 \& 5$ ) to be composed of a microtubular array embedded in a dense matrix that in mast instances gave the granules a filamentous or striated appearance when obliquely or longitudinally sectioned. As shall be demonstrated in a subsequent section of this report, the granules of these cells stained positively for peroxidase.

Macrophages from either control fish (Fig. 6) injected with STCM and recovered from the peritoneal cavity of fish at $60 \mathrm{~min}$ post-injection as well as those from test fish receiving STCM containing Bacillus cereus and recovered from the peritoneal cavity at 30 min post-injection (Fig. 7) lacked the elongate, striated granules observed for the neutrophils, were approximately 8.3 to $11.5 \mu \mathrm{m}$ in diameter and often had a spherical shape. The eccentrically placed nuclei of these cells were typically elongate, frequently indented and demonstrated a moderate amount of heterochromatin along their inner nuclear membrane or in islets. Typically the nucleoplasm of these cells was less electron dense than that observed for the neutrophils. Likewise, their cytoplasm also appeared to be less electron dense than the neutrophils and contained vacuoles, a well developed system of multiple Golgi organelles, prominent arrays of rough endoplasmic reticulum membranes, and numerous lysosome-
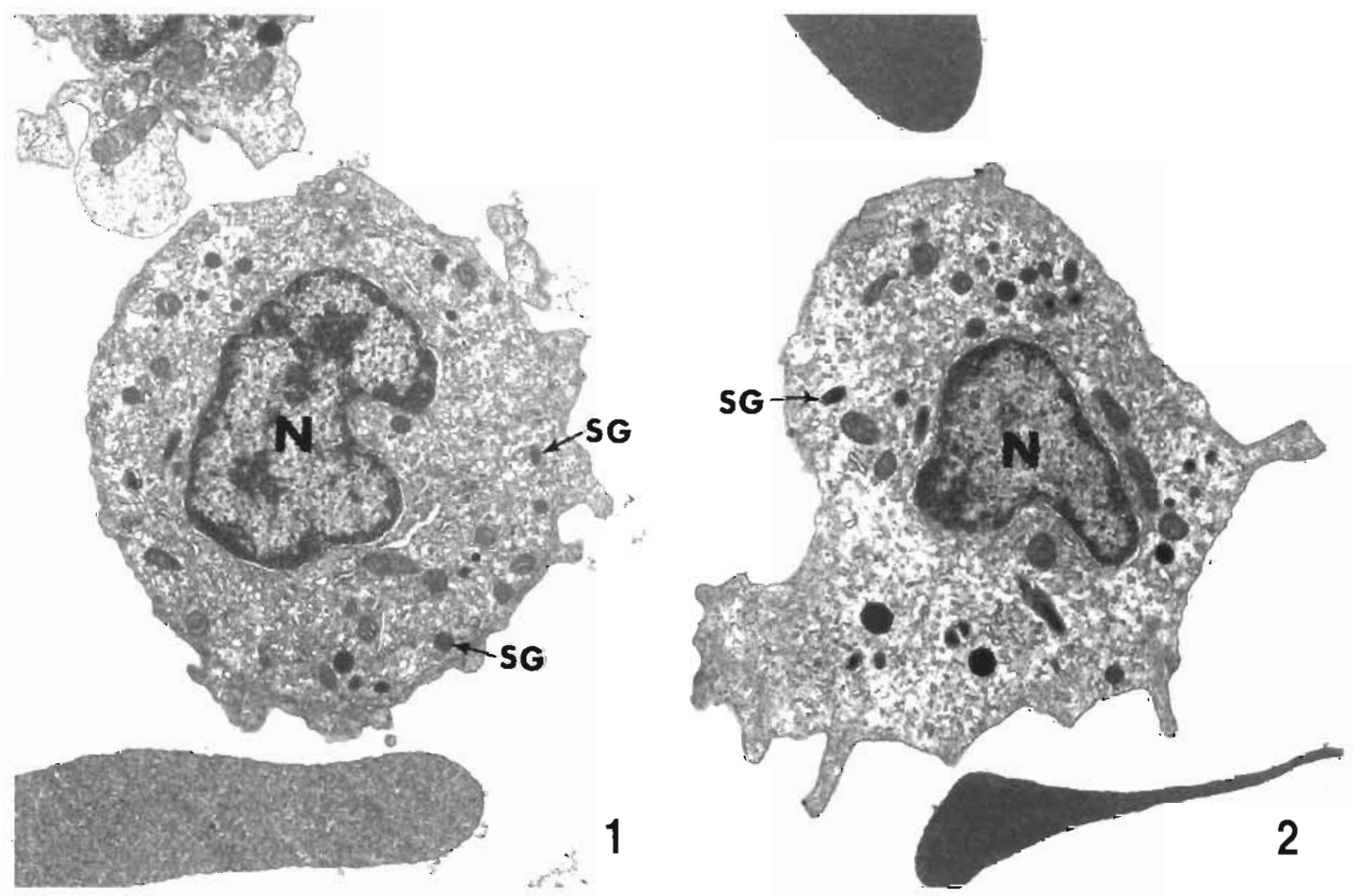

Figs. 1 \& 2. Pleuronectes americanus. Electron micrographs of peritoneal neutrophils from control fish injected i.p. with sterile tissue culture medium (STCM) and recovered $60 \mathrm{~min}$ post-injection. SG: striate granule; N: nucleus. $10065 \times$ 

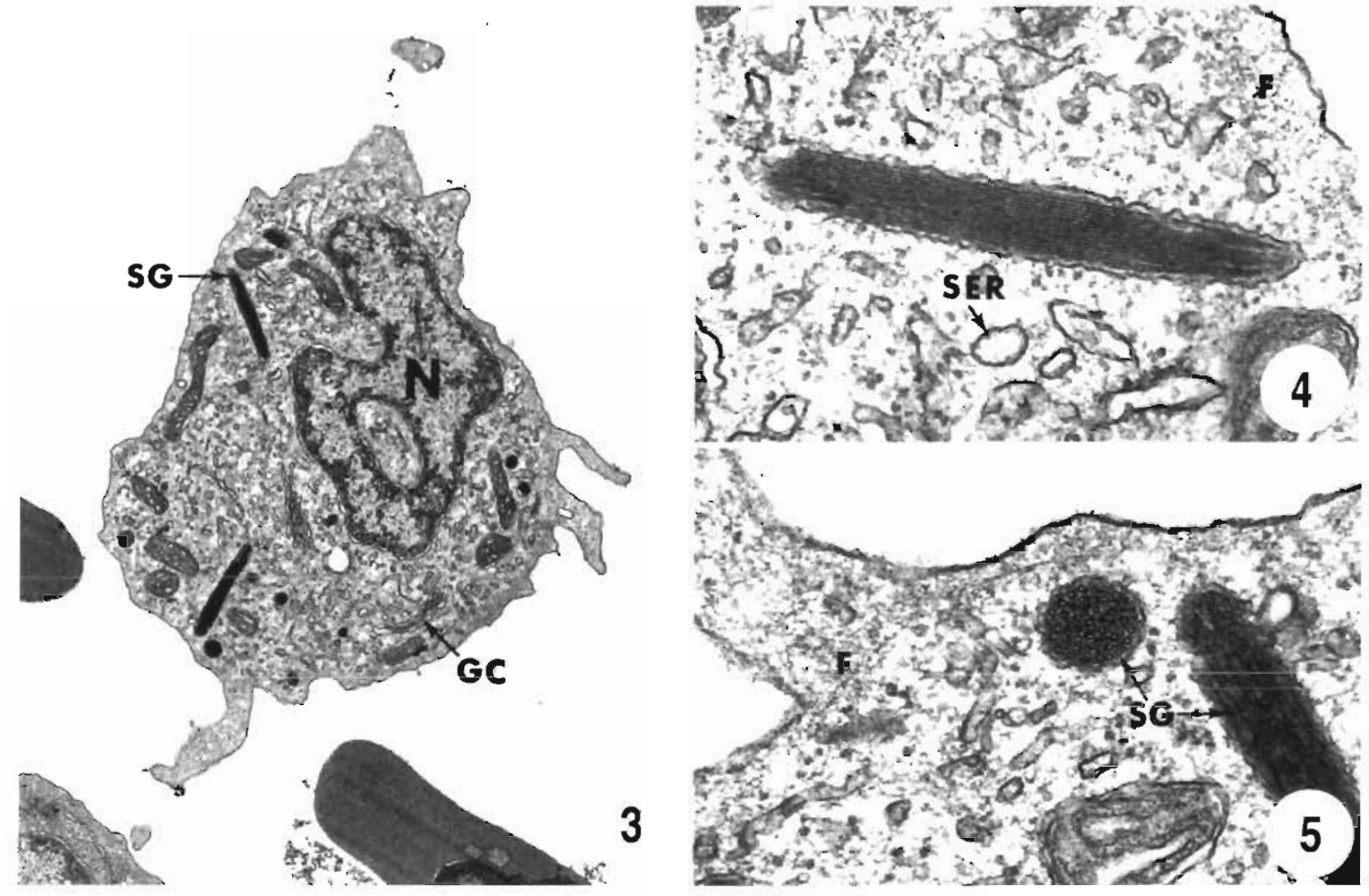

Figs. 3 to 5. Pleuronectes americanus. Fig. 3. Electron micrographs of a peritoneal neutrophil recovered 30 min post-injection with STCM containing Bacillus cereus. This cell more clearly reveals the elongate nature of the striated granules (SG) found within the neutrophil cytoplasm and at higher magnifications the striate (Fig. 4) and/or microtubular nature (Fig. 5) of the granules is readily observed. N: nucleus; GC: Golgi complex; SER: smooth endoplasmic reticulum; F fine filaments. Fig. 3, 9840 $x_{i}$ Figs. 4 \& 5, $56000 \times$

like and/or residual bodies. The macrophage cell membrane was elaborated in some regions to form pseudopodial (P) or lamellipodial (L) extensions which contained fine filaments $(F)$.

As previously described for neutrophils from control fish, macrophages (Fig, 6) recovered from fish injected i.p. only with STCM and recovered $60 \mathrm{~min}$ postinjection appeared to be only moderately activated, as evidenced by their lack of surface elaborations and limited vacuolation. While not studied quantitatively, macrophages (Fig. 7) were found less often than neutrophils in our peritoneal cell preparations collected at 30 min post-injection with STCM containing Bacillus cereus. When observed, they usually failed to contain bacteria within their cytoplasm, but they appeared to have more elaborate surface modifications and larger vacuoles than those recovered from the control fish injected only with STCM (Fig, 6). Exceptions to this generality did exist, however, because some macrophages collected from the peritoneal cavity of test fish at this time interval ( $30 \mathrm{~min}$ ) were obviously capable of recognizing and engulfing the injected test bacterium (Fig 8).

Neutrophils (Fig. 9) from test fish injected i.p. with STCM containing Bacillus cereus and recovered after
30 min were observed to engulf the test bacteria (B). When compared with neutrophils lacking bacteria in their cytoplasm (Figs 1 to 3 ), the nuclei of these cells were often found closer to the cell periphery and their surface membranes were extensively modified to form ruffles (lamellipodia, L) or pseudopodia (P) which contacted adjacent cells. The cytoplasm of these cells often contained a number of vacuoles; however, some of these may have resulted from sections through infoldings in the plasmalemma. Fusion of the cells' striated granules with phagosomes containing bacteria was not documented; however, the dense cap-like structure observed in direct apposition to the bacterial cell wall (CLS; Fig. 9) suggests that such fusion did occur. At 30 min post-injection, neutrophils containing bacteria within their cytoplasm were frequently found in aggregates. Neutrophils from control fish (Figs $1 \& 2$ ) failed to form detectable aggregates, suggesting that aggregation was a response to the presence of internalized bacteria. Firm conclusions on this will, however, have to await the outcome of additional (quantitative) studies.

At 60 min post-injection with STCM containing Bacillus cereus, observations similar to those made at the earlier time interval regarding peritoneal cell iden- 

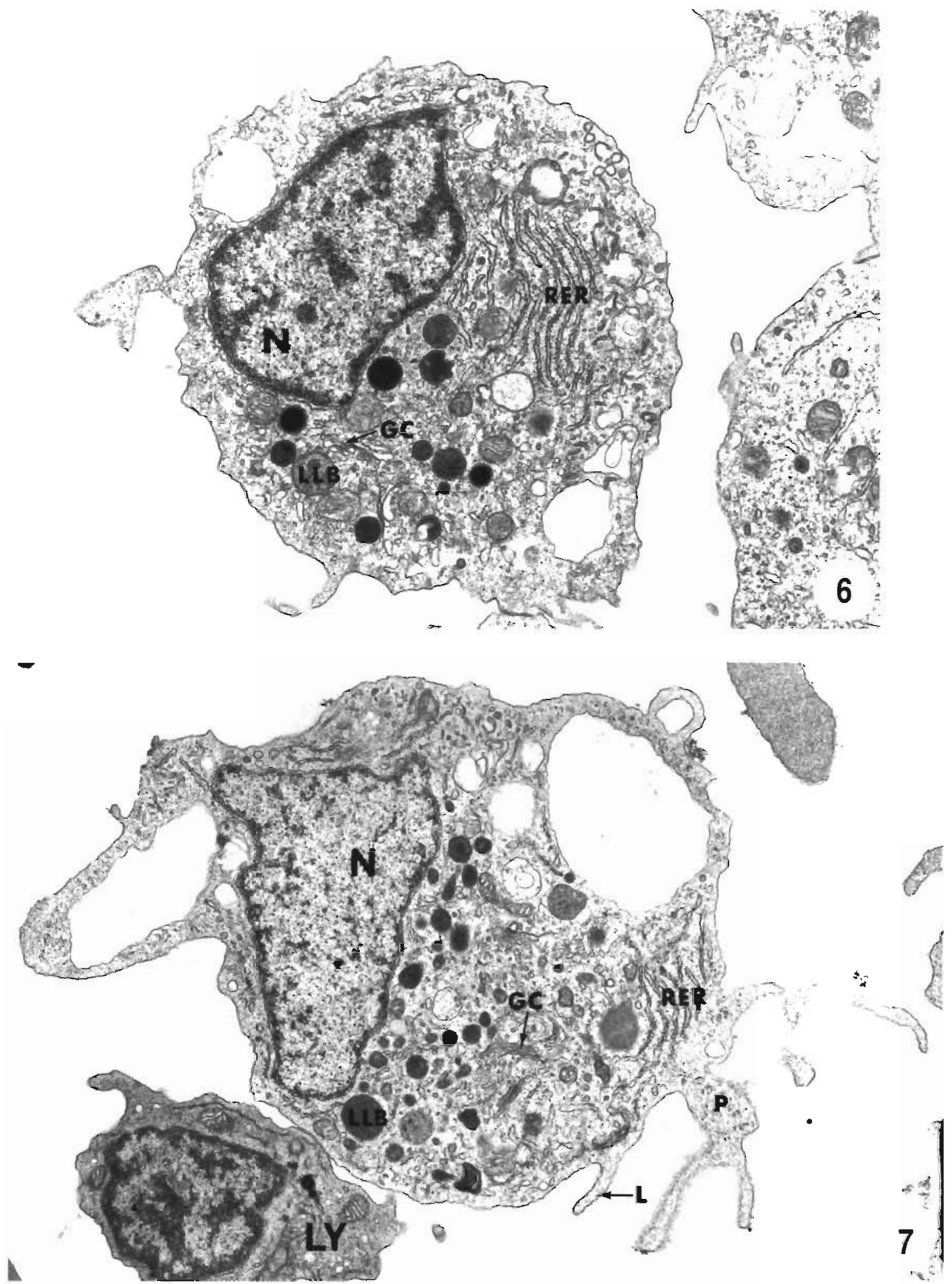

Figs. 6 \& 7. Pleuronectes americanus. Fig. 6. Electron micrograph of a macrophage from control fish injected with STCM and recovered $60 \mathrm{~min}$ post-injection. Fig. 7. Electron micrograph of a pentoneal macrophage recovered at 30 min post-injection with STCM containing Bacillus cereus. The cytoplasm of these cells contaned well developed Golgı organelles (GC), abundant rough endoplasmic reticulum membranes (RER), and lysosome-like bodies (LLB). N nucleus, P pseudopod; L lamellipodium or ruffle; LY. lymphocyte Fig 6, $13200 \times$; Fig. 7.9722x 


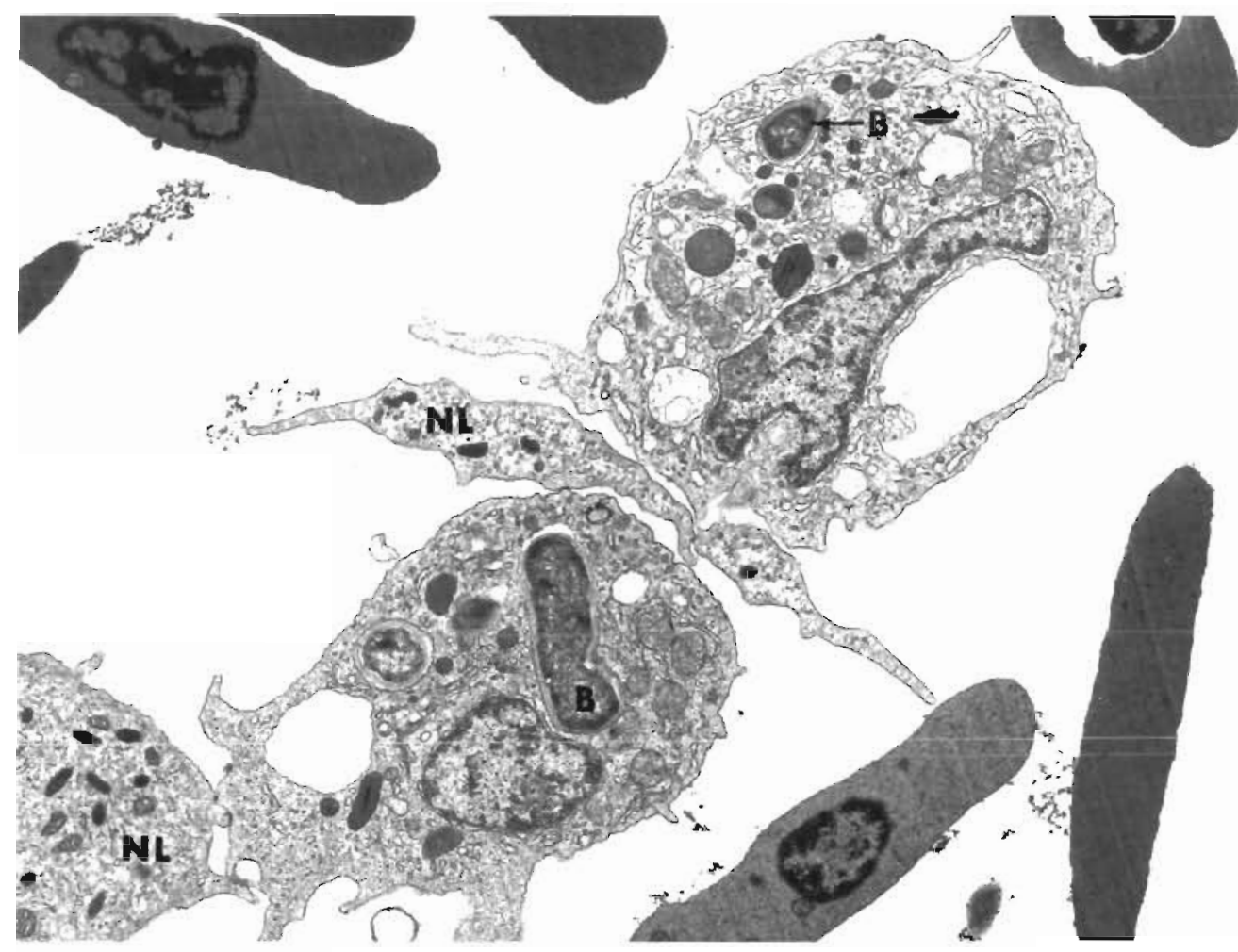

Fig 8 Pleuronectes amencanus. Electron micrograph of 2 pentoneal macrophages recovered at 30 min post-injection with STCM containing Bacillus cereus. Both cells have phagocytozed bacterla (B) and their cytoplasmic characteristics are like the cells shown in Figs 6 \& 7. NL: neutrophli; B. bacterium. $7333 \times$

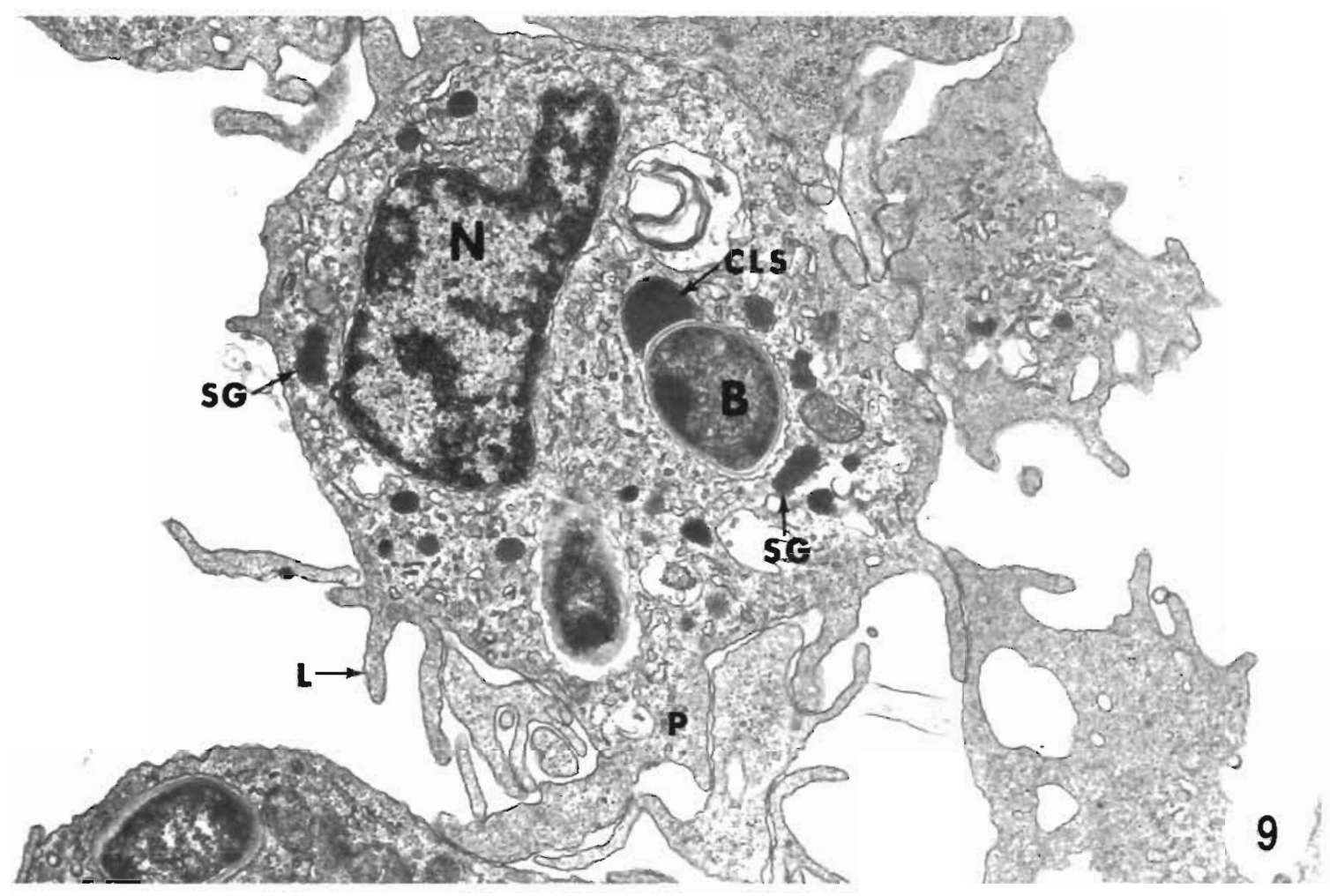

Fig 9 Pleuronectes amencanus Electron micrograph of an activated neutrophil recovered from the peritoneal cavity 30 min postinjection with STCM containing Bacillus cereus This cell has taken up several bactena (B), and its striated granules (SG) can be clearly seen The dense cap-like structure (CLS) suggests a point of granule fusion with a phagosome. P: pseudopodi L: lamellipod or ruffle, $\mathrm{N}$ nucleus. $13333 \times$ 
tification and behavior were repeated, but the following new information on peritoneal leukocytes was obtained. First, there appeared to be a greater tendency for the leukocytes either to aggregate in mixed groups of neutrophils and macrophages (Fig 10) between which extensive membranous contact could be observed, or to be segregated into groups consisting mainly of macrophages (Fig. 11). Second, phagocytes, the identity of which was uncertaun (Fig 12), were found at this stage. These cells appeared hypertrophied perhaps due to an abundance of degenerating engulfed bacteria and the remnants of other cell organelles (e.g. lysosomes, myelin figures, and residual bodies) within their cytoplasm. Unlike other cells containing bacteria, the surfaces of these cells were often smoother and had fewer membranous elaborations (i.e. projections).

The granules in neutrophils (Fig. 13) recovered from the peritoneum of test fish which lacked engulfed Yersinia ruckeri and those from the head kidney neutrophils lacking Y. ruckeri (Fig. 14) exhibited a readily observed positive peroxidase reaction which was not seen in either peritoneal or head kidney neutrophils (cytochemical controls) incubated without DAB. These cells were similar in appearance to those described by routine electron microscopy (Figs. 1 to 3); however, the required incubations and treatment with $D A B$ in- volved in peroxidase staining altered the typical elongate appearance of the strate granules, rendering them more oval to spherical in shape, as well as resulting in overall poor preservation of mitochondrial and other cellular membranes (1.e. plasmalemma, nuclear and vesicular membranes, and those of the endoplasmic reticulum system). In peritoneal neutrophils that had phagocytozed $Y$ rucken (Flgs. 15 \& 16), a less intense peroxidase reaction product was observed for the granules, within phagosomes, and around bacterial cell walls. Macrophages (Fig. 17) with or without engulfed bacteria failed to demonstrate a peroxidase reaction product within therr cytoplasm.

\section{DISCUSSION}

The fine structural cytology of winter flounder neutrophils observed in this study is in agreement with that found for these types of cells in plance Pleuronectes platessa (Ferguson 1976, MacArthur et al. 1984, 1985). The horseshoe-shaped nuclear configuration observed for winter flounder neutrophils has also been reported for the neutrophils of other teleosts (Brelek 1981, Bodammer 1986. Doggett \& Harris 1989, Bodammer et al. 1990). Except for its granules, the cytoplasm of winter flounder neutrophils was unspec-

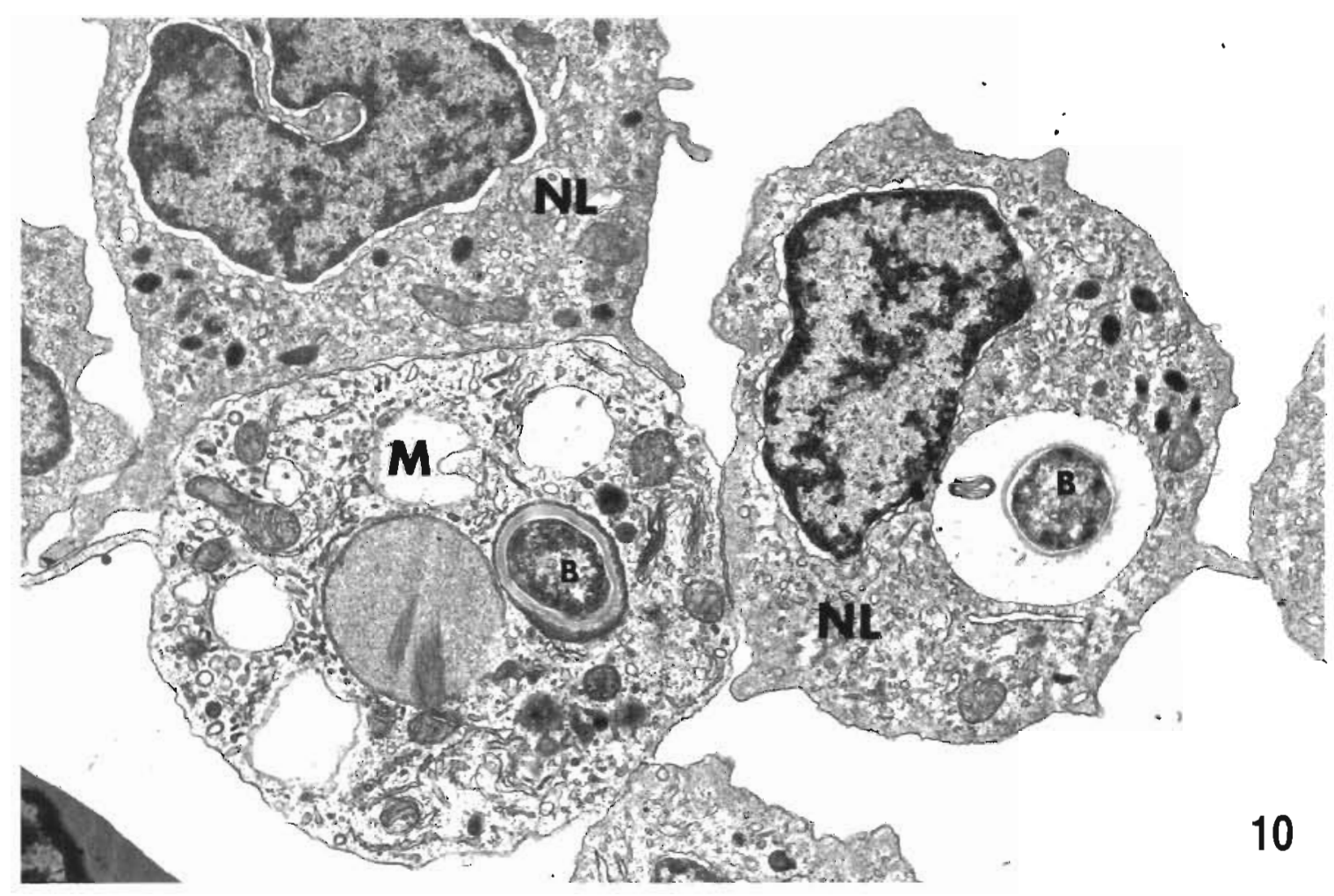

Fig. 10. Pleuronectes americanus. Electron mucrograph of an aggregate of 2 neutrophls (NL) and a macrophage (M) recovered from the peritoneal cavity 60 min post-injection with STCM containıng Bacllus cereus B: bacterium $12000 \times$ 


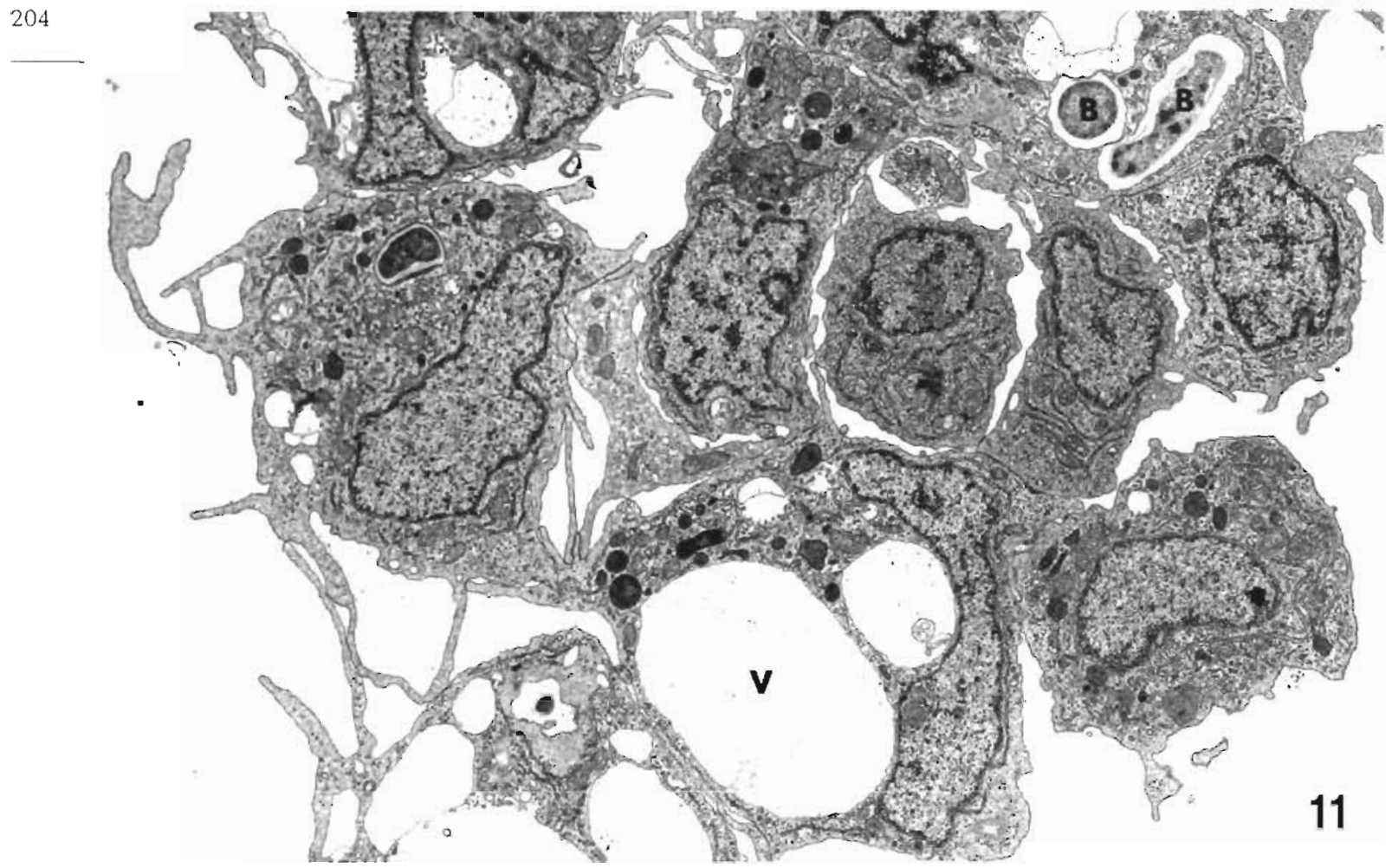

Fig 11 Pleuronectes americanus Electron micrograph of part of an aggregate of activated macrophages recovered from the peritoneal cavity $60 \mathrm{~min}$ post-1njection with STCM containing Bacllus cereus Profıles of degenerating bacteria (B) and large vacuoles $(V)$ were observed within the cytoplasm of these cells. $5700 \times$

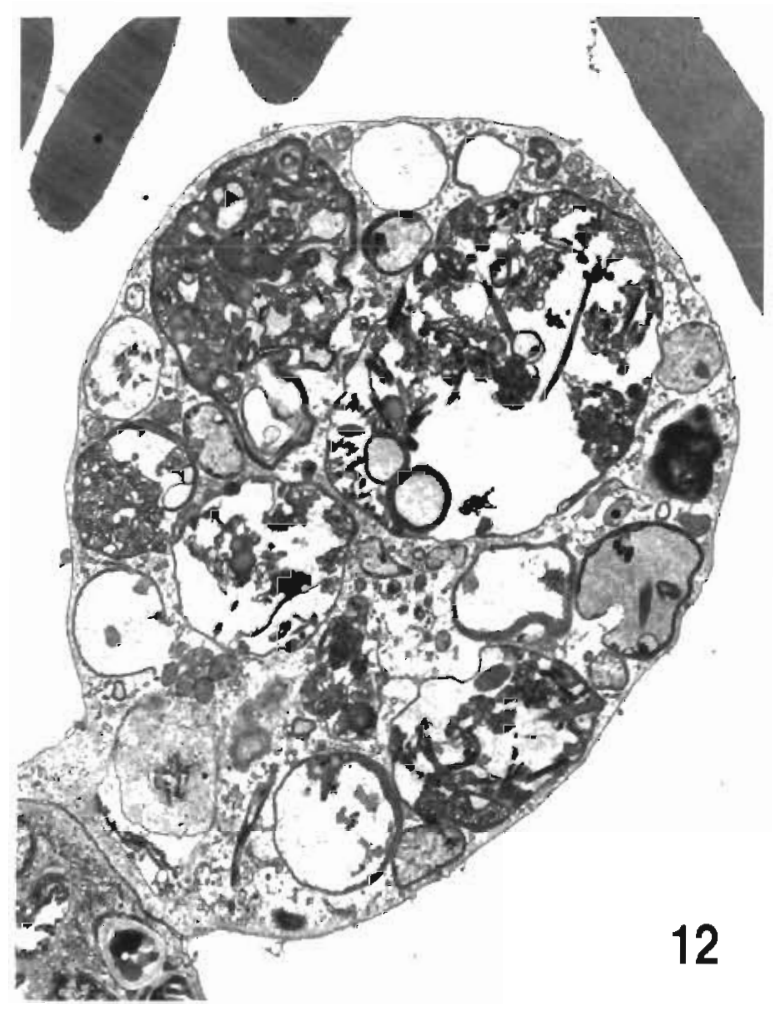

Fig 12. Pleuronectes americanus. Electron micrograph of a hypertrophied phagocyte recovered from the peritoneum 60 min post-injection with STCM containing Bacillus cereus Cell type could not be identified owing to the large numbers of degenerate elements (e g residual bodies, myelın figures. bactenal cells) found within its cytoplasm $6000 x$

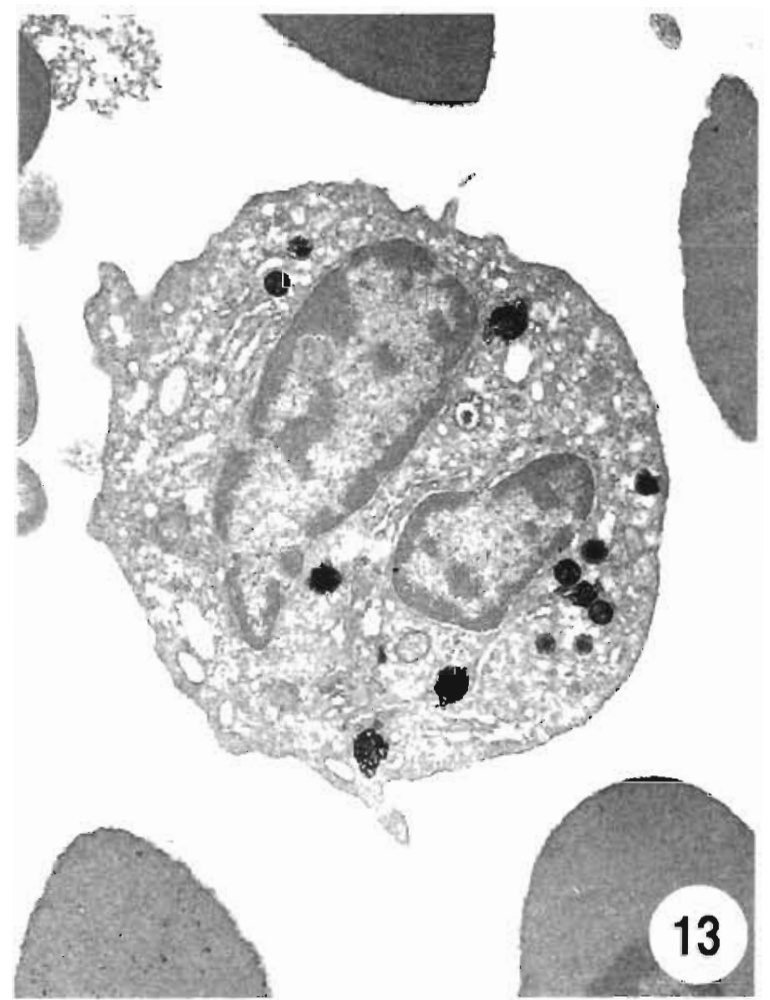

Fig 13 Pleuronectes americanus. Electron micrograph of a peroxidase staned neutrophil recovered from the peritoneum 60 min post-1njection with EMEM containung Yersinia ruckeri This cell which appears to lack bacteria within its cytoplasm contains a number of peroxidase positive granules $14400 x$ 


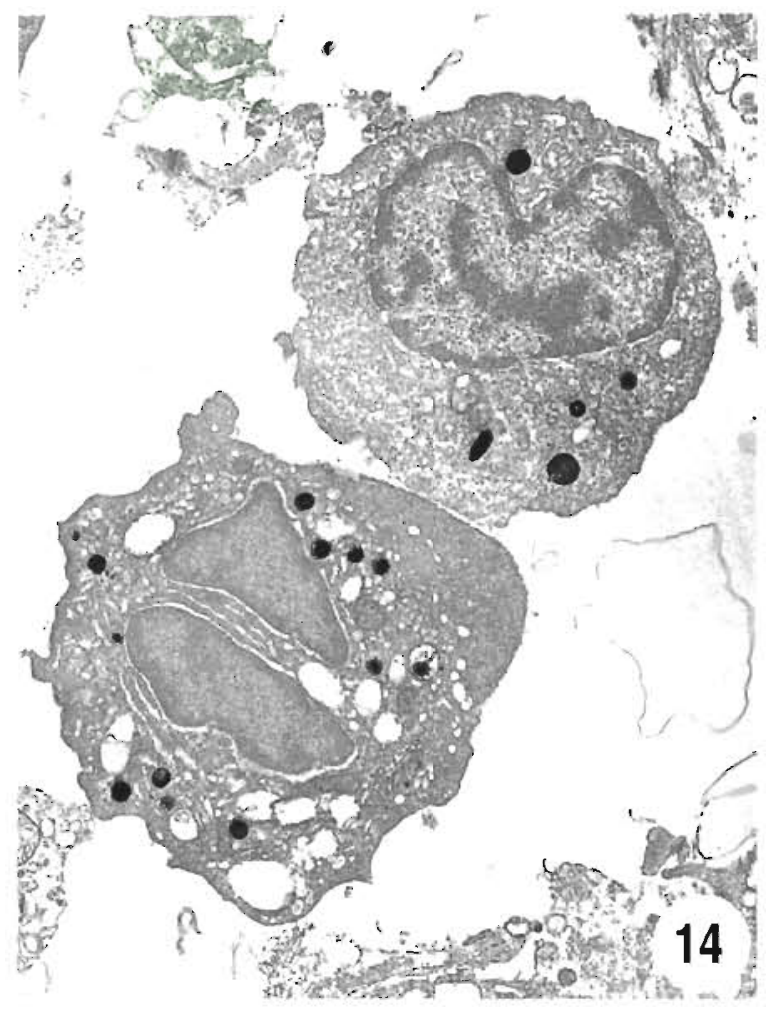

Fig 14 Pleuronectes americanus. Election micrograph of 2 neutrophils from the head kidney of fish that serveci as positive control for the peloxidase method as applied to neutrophils from the peritoneum of fish exposed to EMEM containing Yersinia rucken Note the dense peroxidase staining leaction of the granules in these cells compared to that for granules contaned in the cell depicted in Fig 13 8400x

tacular, its only other organelles were the numerous tubular profiles of smooth endoplasmic reticulum. glycogen-like particles, a promment Golgı complex, a modest amount of rough endoplasmic reticulum, and fine filaments in the cytoplasm subjacent to the cell's plasmalemma. A simular description of neutrophil cytoplasm has been provided for the channel catfish IctaIurus punctatus (Cannon et al. 1980b) and the striped bass Morone saxatulis (Bodammer 1986) Winter flounder neutrophils that appeared to be in an 'activated or stimulated'state, particularly those that had taken up Bacillus cereus (Fig. 9), demonstrated numerous lamellipodial (ruffles) and pseudopodial projections on their surfaces similar in appearance to those of stimulated neutrophils in mammals immediately before and/or durıng phagocytosıs (Berlin \& Oliver 1978, Moore et
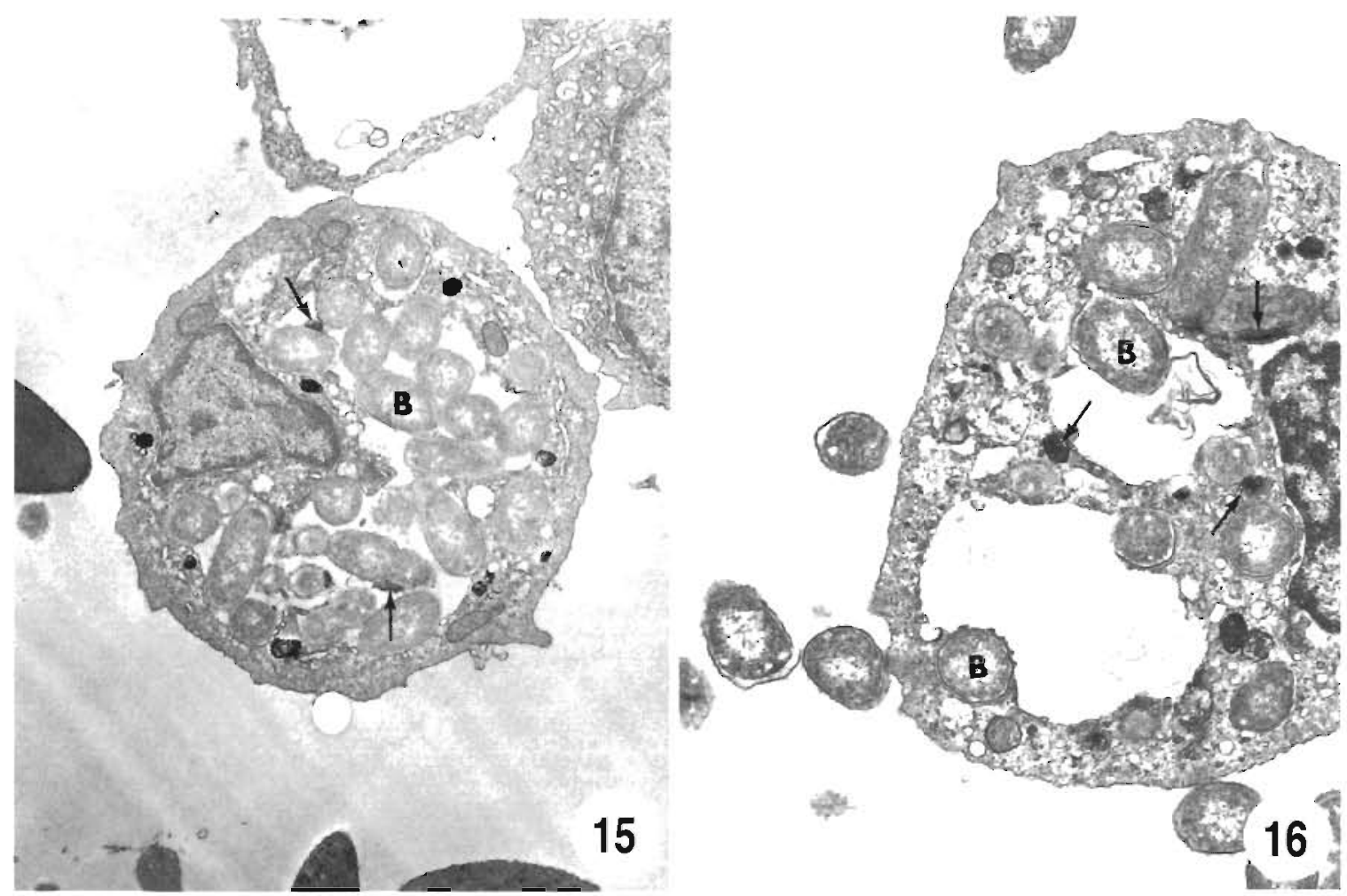

Figs. $15 \& 16$. Pleuronectes americanus Electron micrographs of pentoneal neutrophils recovered from from fish $60 \mathrm{~mm}$ postinjection with EMEM containing Yersinia rucken These bacteria-laden cells demonstrated a weaker positive reaction for peroxidase within their granules than did perıtoneal neutrophils lackıng bacterla (see Fig 13) or head kıdney neutrophils lackıng bacteria (see Fig. 14). In addition, a modest peroxidase reaction product was observed at the level of their phagosomes (arrows) containing the test bacterium (B) Fig. 15,9230x. Fig 16, $14400 \times$ 


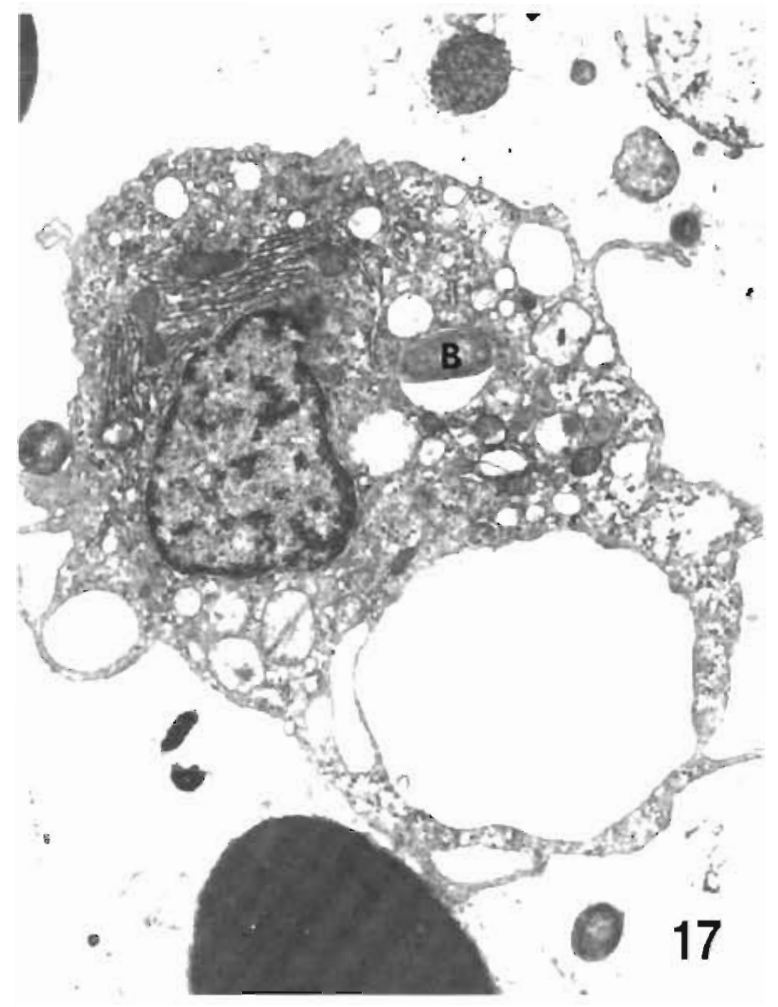

Fig. 17. Pleuronectes americanus. Electron micrograph of a macrophage recovered from the peritoneum $60 \mathrm{~min}$ post-injection with EMEM containing Yersinia ruckeri and stained for peroxidase. The cell was observed to contain a test bacterium (B) but demonstrated no evidence of a peroxidase reaction product within its cytoplasm. $9120 \times$

al. 1978, MacRae et al. 1980, Hoffstein et al. 1982). Membrane elaborations associated with the surface of 'activated or stimulated' neutrophils were not seen on cells that lacked intracellular bacteria; such cells appeared to be quiescent (see Figs. 1 to 3). Although we were unable to identify the cell lineage of the hypertrophied smooth-surfaced phagocytes (Fig. 12), they were morphologically similar to the scanning electron microscopic images of bacteria-laden neutrophils of humans after the in vitro uptake of large numbers of Escherichia coli (MacRae et al. 1980).

The striate or filamentous-appearing granules we observed in winter flounder neutrophils were similar in shape and substructure to those observed in the heterophils of plaice (Ferguson 1976) and other teleost species (Cannon et al. 1980b, Bodammer 1986. Hine et al, 1986, Roubal 1986, Suzuki 1986, Hine \& Wain 1988, Doggett \& Harris 1989, Fujimaka \& Isoda 1990). As mentioned earlier, because of the orientation of most of the neutrophil granules our images failed to reveal their microtubular nature most of the time (Figs. $4 \& 5$ ); thus, they most often resembled the striate or filamentous granules described by others.
The positive peroxidase reaction we found in the granules of winter flounder peritoneal and head kidney neutrophils (Figs. $13 \& 14$ ) is important in their identification and supports the hypothesis that the neutrophils are capable of killing microbial pathogens. The presence of peroxidase in the bacteria-containing phagosomes of winter flounder neutrophils provides supportive evidence that these cells have microbicidal capability via the $\mathrm{H}_{2} \mathrm{O}_{2}$-peroxidase-halide system thought to be operant in the neutrophils of other fish species (Nash et al. 1987, Ainsworth 1992). Peroxidase positive granules have also been observed in both developing and mature neutrophils in plaice (Ellis 1976) and in other species of teleosts (Cannon et al. 1980a, Bielek 1981, Suzuki 1984, Bayne 1986, Hine et al. 1986, Doggett et al. 1987, Finco-Kent \& Thune 1987, Bodammer et al. 1990). Presently, the only explanation we can provide for the modest peroxidase reaction we observed in the granules or phayusomes (Figs. $15 \& 16$ ) of neutrophils containing bacteria was that the discharge of their granules' contents into phagosomes and/or surrounding cytoplasm resulted in enzyme quantities that were below the detection limits of the cytochemical method employed. Peroxidase-bearing phagosomes in teleost neutrophils have been reported in both the rockfish Sebastes schlegli and rainbow trout Oncorhynchus mykiss by Suzuki (1984) and in channel catfish (Finco-Kent \& Thune 1987).

As reviewed by Ainsworth (1992), most observations on the phagocytic ability of neutrophils in teleost fish species have resulted from in vitro studies utilizing various inert particles and/or bacteria. In vivo observations on the phagocytic behavior of teleost neutrophils have been reported for rainbow trout during the inflammatory response to intramuscular, intraperitoneal, or periorbital injections of heat-killed Staphylococcus aureus (Finn \& Nielson 1971), in the peripheral blood neutrophils of the sockeye salmon Oncorhynchus nerka after engulfment of Lactobacillus brevis (Bell 1976), and by systemic neutrophils in tilapia Oreochromis niloticus Trewavas that had taken up both attenuated Aeromonas salmonicida and colloidal carbon (Doggett \& Harris 1989). In in vivo studies similar to the one reported here, electron microscopic observations of peritoneal neutrophils from tilapia and carp Cyprinus carpio L. have clearly shown them to be phagocytic after $24 \mathrm{~h}$ exposure to zymosan particles (Suzuki 1986), and as mentioned before, MacArthur et al. (1984) have observed that neutrophils in plaice engulfed oyster glycogen and Vibrio alginolyticus after $24 \mathrm{~h}$. While they have not identified cell type, Noya et al. (1995) have shown that peritoneal granulocytes in the gilthead seabream Sparus aurata take up the pathogen Pasteurella piscicida within 60 min after i.p. injection. Our observations on the 
phagocytic capability of winter flounder peritoneal neutrophils are in good accord with the 3 previously cited studies.

As we have shown, winter flounder peritoneal macrophages phagocytozed both types of test bacteria (Figs. 8, 10, 11 \& 17). This is not surprising because recent reviews by Blazer (1991) and Secombes \& Fletcher (1992) have indicated that macrophages are consistently observed among various teleosts to be the most efficient type of leukocyte involved in the engulfment of pathogens and necrotic debris resulting from inflammatory responses or other types of degenerative processes (e.g. cellular necrosis or apoptosis). In addition, Daniels (1988) has clearly demonstrated the in vitro capability of winter flounder macrophages to engulf and kill Vibrio alginolyticus under a variety of culture conditions.

The lamellipodia and pseudopodia we observed in our 30 and 60 min preparations of winter flounder peritoneal macrophages were ultrastructurally similar to those reported for activated trout peritoneal macrophages during the phagocytosis of formalin-killed Aeromonas salmonicida (Zelikoff \& Enane 1991) and for those of activated murine peritoneal macrophages during the phagocytosis of rabbit erythrocytes and latex spheres (Polliack \& Gordon 1975) or sheep red blood cells as reported by Orenstein \& Shelton (1977). The cytoplasmic and nuclear features of the macrophages studied herein were comparable to those reported for peritoneal macrophages in plaice (MacArthur et al. 1984) and striped bass (Bodammer 1986).

In summary, we have demonstrated that winter flounder neutrophils and monocytes/macrophages are capable of bacterial engulfment after short periods of exposure to the test organisms within the peritoneal cavity. Although we have not quantified the results of our work nor studied the kinetics in a detailed manner, our results are in keeping with the in vivo studies performed by MacArthur et al. (1984) who found that neutrophils were the first cells to phagocytoze marine vibrios in the peritoneal cavity of plaice and that the response of macrophages to the test organism was less rapid. Further, MacArthur et al. (1985) showed that plaice monocytes migrated rapidly (after only $2 \mathrm{~h}$ ) into the vascular system when stimulated by foreign erythrocytes in the blood stream. Despite the latter results, we were surprised to observe the speed of the phagocytic response of peritoneal neutrophils and macrophages in the winter flounder (it occurred in only $30 \mathrm{~min}$ ). We intend to fully characterize the kinetics of these and other leukocyte responses in the future. Until further information is available, we must presume that the neutrophils and macrophages studied herein were resident in the peritoneal cavity at the time the test bacteria were introduced.
Acknowledgements. We thank John Ziskowski for collecting the winter flounder used in this study and Debra C. Spitzer for her fine technical assistance in electron microscopy. The manuscript benefitted from reviews provided by Drs D. P. Anderson, R. E. Wolke, A. Calabrese, Ms Sharon MacLean, and others.

\section{LITERATURE CITED}

Ainsworth AJ (1992) Fish granulocytes: morphology, distribution, and function. In: Faisal M, Hetrick FM (eds) Annual review of fish diseases, Vol II. Pergamon Press, New York, p $123-148$

Bayne CJ (1986) Pronephric leukocytes of Cyprinus carpio isolation, separation and characterization. Vet Immunol Immunopathol 12:141-151

Bell GR (1976) Preliminary observations on phagocytosis in the peripheral blood of sockeye salmon (Oncorhynchus nerka). Fish Pathol 10:237-241

Berlin RD, Oliver JM (1978) Analogous ultrastructure and surface properties during capping and phagocytosis in leukocytes. J Cell Biol 77:789-804

Bielek E (1981) Developmental stages and localization of peroxidatic activity in the leucocytes of three teleost species (Cyprinus carpio L.; Tinca tinca L.; Salmo gairdneri Richardson). Cell Tissue Res 220:163-180

Blazer VS (1991) Piscine macrophage function and nutritional influences: a review. J Aquat Anim Health 3:77-86

Bodammer JE (1986) Ultrastructural observations on peritoneal exudate cells from the striped bass. Vet Immunol Immunopathol 12:127-140

Bodammer JE, Anderson DP, Dixon OM (1990) Ultrastructure of the spleen and head kidney of striped bass. J Aquat Anim Health 2:182-193

Bridges DW, Chech JJ Jr, Pedro DN (1976) Seasonal hematological changes in winter flounder, Pseudopleuronectes americanus. Trans Am Fish Soc 105:596-600

Cannon MS, Mollenhauer HH, Cannon AM, Eurell TE, Lewis DH (1980a) Ultrastructural localization of peroxidase activity in neutrophil leukocytes of Ictalurus punctatus. Can J Zool 58:1139-1143

Cannon MS, Mollenhauer HH, Eurell TE, Lewis DH, Cannon AM, Tompkins C (1980b) An ultrastructural study of the leukocytes of the channel catfish, Ictalurus punctatus. J Morph 164:1-23

Daniels TG (1988) The development of a fluorescent in vitro method to test the phagocytic engulfment and intracellular bactericidal abilities of macrophages from winter flounder (Pseudopleuronectes americanus). Master's thesis, University of Rhode Island, Kingston, RI, USA

Doggett TA, Harris JE (1989) Ultrastructure of the peripheral blood leucocytes of Oreochromis mossambicus. J Fish Biol 33:747-756

Doggett TA, Wrathmell AB, Harris JE (1987) A cytochemical and light microscopic study of the peripheral blood leucocytes of Oreochromis mossambicus, Chichlidae. J Fish Biol 31:147-153

Ellis AE (1976) Leucocytes and related cells in the plaice Pleuronectes platessa. J Fish Biol 8:143-156

Ferguson HW (1976) The ultrastructure of plaice (Pleuronectes platessa) leucocytes. J Fish Biol 8:139-142

Finco-Kent D, Thune RL (1987) Phagocytosis by catfish neutrophils. J Fish Biol 31(Suppl A):41-49

Finn JP, Nielson NO (1971) The inflammatory response of rainbow trout. J Fish Biol 3:463-478 
Fujimaka Y, Isoda M (1990) Fine-structural study of leucocrtes in the goldfish, Carassus auratus. J Fish Biol 36: $821-831$

Hine PM (1992) The granulocytes of fish. Fish Shellfish Immunol 2:79-98

Hine PM, Wain JM (1988) Ultrastructural and cytochemical observations on the granulocytes of the sturgeon, Acipenser brevirostrum [Chondrostel]. J Fish Biol 33: $235-245$

Hine PM, Wain JM, Boustead NC, Dunlop DM (1986) Light and electron microscopic studies on the enzyme cytochemistry of leucocytes of eels, Anguilla species. J Fish Biol 29:721-735

Hoffsteın ST, Friedman RS, Weissman G (1982) Degranulation, membrane addition, and shape change during chemotactic factor-induced aggregation of human neutrophils. J Cell Biol 95:234-241

Laudan R, Stolen JS, Cali A (1987) The immunomodulating effect of the microspondian Glugea stephani on the humoral response and immunoglobulin levels in winter flounder, Pseudopleuronectes americanus. J Fish Biol 31 (Suppl A):155-160

Laudan R, Stoien jS, Cali A (1989) The effect of the microsporidin Glugea stephani on the immunoglobulin levels of juvenile and adult winter flounder (Pseudopleuronectes amencanus). Dev Comp Immunol 13:35-41

MacArthur JI, Fletcher TC (1985) Phagocytosis in fish. In: Manning MJ, Tatner MF (eds) Fish immunology. Academic Press, London, p 29-46

MacArthur JI, Fletcher TC, Pirie BJS, Davidson RJL, Thompson AW (1984) Peritoneal inflammatory cells in plaice, Pleuronectes platessa L.: effects of stress and endotoxin. J Fish Biol 25:69-81

MacArthur JI, Thomson AW, Fletcher TC (1985) Aspects of leukocyte migration in the plaice, Pleuronectes platessa $\mathrm{L}$. J Fish Biol 27:667-676

MacRae EK, Pryzwansky KB, Cooney MH, Spitznagel JK (1980) Scanning electron microscopic observations of early stages of phagocytosis of $E$. coll by human neutrophils. Cell Tissue Res 209:65-70

Moore PL, Bank HL, Brissie NT, Spicer SS (1978) Phagocytosis of bacteria by polymorphonuclear leucocytes. A freeze-fracture, scanning electron microscope, and thinsection investigation of membrane structure. J Cell Biol 76:158-174

Murchelano RA (1989) Fish as sentinels of environmental health. ("mted States Department of Commerce, Washington, DC, NOAA Technical Memorandum NMFS-F/NEC61, p $1-16$

Murchelano RA, Wolke RE (1991) Neoplasms and nonneoplastic liver lesions in winter flounder, Pseudopleu-

Responsible Subject Editor: T. Evelyn, Nanaimo,

British Columbia, Canada ronectes americanus, from Boston Harbor, Massachusetts Environ Health Perspect 90:17-26

Nash KA. Fletcher TC. Thomson AW (1987) Effect of opson1zation on oxidative metabolism of plaice (Pleuronectes platessa L.) neutrophils. Comp Biochem Physiol 86B:31-36

Noya M. Magarinos B. Toranzo AE, Lamas J (1995) Sequential pathology of experimental pasteurellosis in gilthead seabream Sparus aurata. A light- and electronmicroscopic study. Dis Aquat Org 21:177-186

Orenstein JM, Shelton E (1977) Membrane phenomena accompanying erythrophagocytosis. A scanning electron microscope study. Lab Invest 36:363-374

Polliack A, Gordon S (1975) Scanning electron microscopy of murine macrophages. Surface characteristics dunng maturation, activation, and phagocytosis. Lab Invest 33 469-477

Robohm RA, Brown C. Murchelano RA (1979) Comparison of antibodies in marne fish from clean and polluted waters of the New York Bight: relative levels against 36 bacteria Appl Environ Microbiol 38:248-257

Roubal FR (1986) Blood and other possible inflammatory cells in the sparid Acanthopagrus australis [Gunther]. J Fish Bioi 28:573-593

Secombes CJ, Fletcher TC (1992) The role of phagocytes in the protective mechanisms of fish. In: Faisal M. Hetrick FM (eds) Annual review of fish diseases, Vol II. Pergamon Press, New York, p 53-71

Spurr AR (1969) A low viscosity epoxy resin embedding medium for electron microscopy. J Ultrastruct Res 26: $31-43$

Stolen JS, Draxler S, Nagle JJ (1984) A comparison of temperature-mediated immunomodulation between two species of flounder. Immunol Commun 13:245-253

Stolen JS, Gahn T, Kasper V. Nagle JJ (1985) Natural and adaptive immunity in marine teleosts to bacterial isolates from sewage studies. In: Manning MJ, Tatner MF (eds) Fish immunology. Academic Press, London, p 207-220

Suzuki K (1984) A light and electron microscope study on the phagocytosis of leucocytes in rockfish and rainbow trout. Bull Jap Soc Scient Fish 50:1305-1315

Suzuki K (1986) Morphological and phagocytic characteristics of peritoneal exudate cells in tilapia. Oreochromis nilotacus (Trewavas), and carp. Cyprinus carpio L. J Fish Biol $29: 349-364$

Terzakis JA (1968) Uranyl acetate, a stain and a fixative J Ultrastruct Res 22:168-184

Zelıkoff JT, Enane NA [1991) Assays used to assess the activation state of rainbow trout peritoneal macrophages. In Stolen. JS, Fletcher TC, Anderson DP, Kaattari SL, Rowley AF (eds) Techriques in Fish Immunology. FITC 1, Chap 11. SOS Publications, Fair Haven, CT, p 107-120

Manuscript first received: June 20,1994

Revised version accepted: November 8, 1995 